\title{
Memorias de un normalista pampeano
}

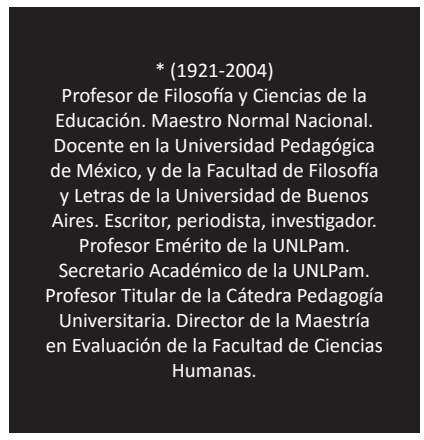

Memorias de un normalista pampeano La Arena 8 de junio de 1980

\section{Tiempo y desvelo}

Con el tiempo se han ido borrando las huellas. El Tiempo, esa dimensión metafísica acerca del cual ningún profesor lograba convencerme con sus definiciones. No, yo no me refería al tiempo cronológico. $\mathrm{Ni}$ al cronómetro con que se nos medía la velocidad de los cien metros llanos, en vísperas de torneos atléticos. Yo intuía que el Tiempo como el Silencio, eran otra cosa.

-Ahora son las 12, decía Facio mirando el reloj. Y dentro de una hora será la una...Eso en el tiempo y lo demás son macanas...

-Para mí el tiempo es algo gastronómico... Yo no veo la hora de la salida ¡Tengo un ragú"-, opinaba el gordito Fioravanti.

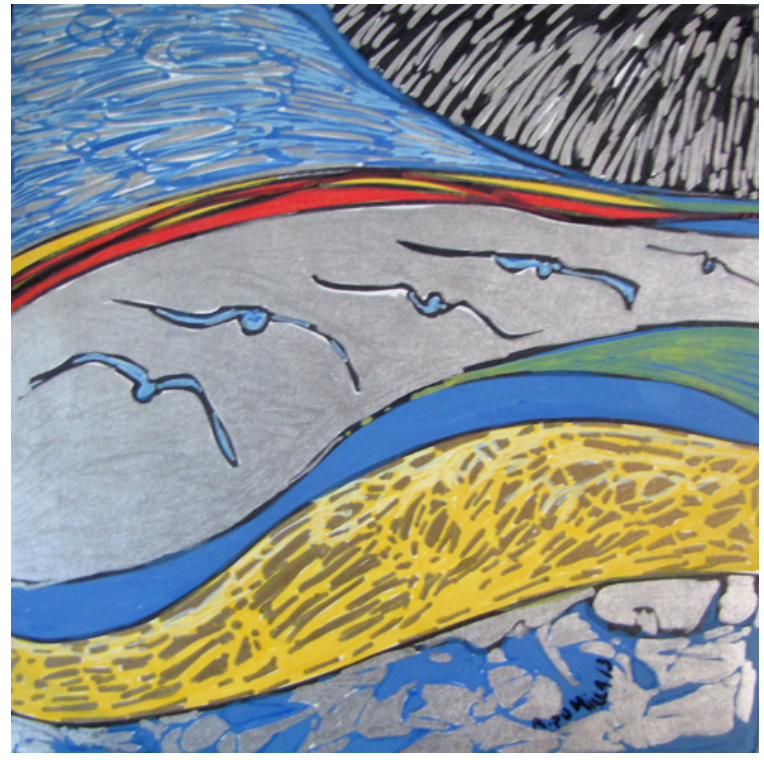

S/T, pintura. Raquel Pumilla

-Ah, el tiempo, el tiempo...! Yo no veo la hora de recibirme y entrar en la carrera de Derecho...!, -intervenía Laura.

- ¡Buena viva sos vos...! Te metés en el magisterio, le quitás el lugar a otro u otra con verdadera vocación de maestro y después... chau Pinela!-, refutaba Victorio.

Siempre nos saltamos del tema. Cada uno vivía el tiempo a su antojo. Yo sentía su dolorosa carga, oprimiéndome el alma. En las clases de Física me aburría soberanamente cuando la profesora hablaba de "masa, energía, materia, velocidad...” Por ahí aparecía el tiempo físico, concreto, en alguna fórmula, que tenía algo de cábala irreductible en mi intimidad.

$\mathrm{Si}$, el tiempo ha ido borrando las huellas ¿Qué huellas? Las de aquella angustia existencial que me ahogaba cuando medía el porvenir con el escalímetro de mi tiempo. Supongo que ni Einstein ni el más encumbrado teórico de 
la relatividad podrían haberme convencido de que había entonces otro tiempo distinto del mío. Yo me sumergía en el laberinto de mi interioridad, en busca del tiempo pasado, del tiempo presente, del tiempo futuro: el tiempo.

No sabía nada de Proust. Acaso en el hubiese hallado una respuesta o, en todo caso, una clave para desentrañar aquel enigmático desvelo. Hoy estoy seguro que no. intuyo que ni el mismo Proust sabía lo que buscaba. en la vieja Psicología, de Guerrero, una cita de San Agustín se aproximaba a lo que inquiría en mi búsqueda: "No sé lo que es, pero sé en qué consiste...". Correcto, esa era "la vivencia" del Tiempo. Pero su consistencia era menos que su esencia. Y era hacia lo esencial donde se orientaba mi búsqueda. Me metí en el Martín Fierro, ese libro al que tantos citan como el Quijote y El Moreno, encontré un rastro. Decía, en efecto Fierro: "Moreno, voy a decir,/ según mi saber alcanza: el tiempo sólo es tardanza/ de lo que está por venir;/no tuvo nunca principio/ ni jamás acabará/, /porque el tiempo es una rueda, y rueda es eternidá...”

En la cuarteta final del octosílabo de la "paya", se entremezclaba lo físico con lo metafísico: "Y si el hombre lo divide, /sólo lo hace, en mi sentir, /por saber lo que ha vivido / o le resta que vivir".

Me aferré a esa idea. No cuestioné -no habría podido hacerlo- la fragilidad de aquel concepto: “...la rueda es eternidá". Pero supe, de ahí en más, que mi Tiempo era intransferible. Como el de los otros. Con la única diferencia, para aquellos años de adolescente, de que en mí, aquella noción (hoy genéticamente descripta por Piaget) era algo así como el tábano socrático: me picaba y me mantenía despierto. Obsesivamente. Como hoy, aunque las huellas se hayan borrado, y el tiempo -en cuanto duración- siga constituyendo el mismo, viejo enigma que me desvelaba. Sensillamente porque era mi Tiempo. Es mi Tiempo.

\section{Memorias de un normalista pampeano La Arena 1 de julio de 1980}

\section{Racconto de soledad}

Volví. A remolque de un sueño, me acerqué a sus muros. Lo hice de noche, furtivamente. Me quedé mirándola, entre el asombro y el desasosiego. Aquel edificio enorme de fastuosa arquitectura, escondía otra imagen; encerraba otro Tiempo. Solamente, en la esquina, la "casa de la Directora” permanecía igual. Ahora, tampoco está. La "piqueta del progreso" -así la llaman- no sabe de sentimentalismos. ¡Cómo hubiera querido recorrer de nuevo las viejas aulas, los pasillos, los corredores, sus solanas fiesteras...!

Me pregunté (y me pregunto si la vieja casona de los Mason -que antes de convertirse en Escuela Normal había cumplido otras funciones apenas iniciado el siglo XX- no hubiera podido convertirse en el Museo Didáctico de la provincia. Pensé que por salvar un árbol (el aguaribay del Perito Moreno), los constructores del Instituto "Bernasconi”, verdadero palacio de la educación, no habían vacilado, bajo la dirección del arquitecto Waldorp, en modificar el proyecto original. $\mathrm{Y}$ el aguaribay centenario sigue en pie, transformando en monumento histórico...

Hubiera sido lindo, si, encontrar al viejo Don Germán cuidando de la casa. Más lindo todavía, saber que en el recinto de la pedagogía, podía tropezar a boca de jarro con aquel letrero enrome, de madera terciada, donde podía leerse "Maestro, el alumno te mira..."

Pero no, no hay nada de eso. La casa ya no existe. Apenas si existo yo, transido de trizteza, con mil años sobre mis espaldas. A la luz de la luna, entrecerrando los ojos, penetrando la noche con los oidos, escucho rumores: risas, cantares, serenatas.

¿Te acordás, Quino? ¿Recordas, César? Allí (aquí) estábamos, soñando el sueño del mandolín y la guitarra. Aquí mismo, bajo el ausente ventanal, con nuestros trémolos de sangre joven, desparramábamos el fervor de la estudiantina. ¿Adónde están todos? ¿Qué bordoneo se los llevó lejos? La sucesión de rostros, de gestos, de nombres, es como el turbulento fluir de un río.

Es cierto. "El alumno te mira, maestro". Pronto volveré a las aulas, las del nuevo edificio. Entraré en ellas sigilosamente, para no espantar los recuerdos. Les diré a mis alumnos normalistas que allí, en el inmenso patio desolado, hubo una vez una casa, acogedora y humilde, donde había tiempo y espacio para la pena y la alegría. Y que yo fui un duende triste alegre que se metió en sus paredes para siempre. 